\title{
Front Matter: Volume 11254
}

, "Front Matter: Volume 11254," Proc. SPIE 11254, Nanoscale Imaging, Sensing, and Actuation for Biomedical Applications XVII, 1125401 (4 March 2020); doi: 10.1117/12.2569677

SPIE. Event: SPIE BiOS, 2020, San Francisco, California, United States 


\title{
PROGRESS IN BIOMEDICAL OPTICS AND IMAGING

\section{Nanoscale Imaging, Sensing, and Actuation for Biomedical Applications XVII}

\author{
Dror Fixler \\ Ewa M. Goldys \\ Sebastian Wachsmann-Hogiu \\ Editors
}

2-3 February 2020

San Francisco, California, United States

Sponsored by

SPIE

Cosponsored by

Prizmatix Ltd. (Israel) (United States)

Published by

SPIE 
The papers in this volume were part of the technical conference cited on the cover and title page. Papers were selected and subject to review by the editors and conference program committee. Some conference presentations may not be available for publication. Additional papers and presentation recordings may be available online in the SPIE Digital Library at SPIEDigitalLibrary.org.

The papers reflect the work and thoughts of the authors and are published herein as submitted. The publisher is not responsible for the validity of the information or for any outcomes resulting from reliance thereon.

Please use the following format to cite material from these proceedings:

Author(s), "Title of Paper," in Nanoscale Imaging, Sensing, and Actuation for Biomedical Applications XVII, edited by Dror Fixler, Ewa M. Goldys, Sebastian Wachsmann-Hogiu, Proceedings of SPIE Vol. 11254 (SPIE, Bellingham, WA, 2020) Seven-digit Article CID Number.

ISSN: 1605-7422

ISSN: $2410-9045$ (electronic)

ISBN: 9781510632714

ISBN: 9781510632721 (electronic)

Published by

SPIE

P.O. Box 10, Bellingham, Washington 98227-0010 USA

Telephone +13606763290 (Pacific Time) · Fax +1 3606471445

SPIE.org

Copyright @ 2020, Society of Photo-Optical Instrumentation Engineers.

Copying of material in this book for internal or personal use, or for the internal or personal use of specific clients, beyond the fair use provisions granted by the U.S. Copyright Law is authorized by SPIE subject to payment of copying fees. The Transactional Reporting Service base fee for this volume is $\$ 21.00$ per article (or portion thereof), which should be paid directly to the Copyright Clearance Center (CCC), 222 Rosewood Drive, Danvers, MA 01923. Payment may also be made electronically through CCC Online at copyright.com. Other copying for republication, resale, advertising or promotion, or any form of systematic or multiple reproduction of any material in this book is prohibited except with permission in writing from the publisher. The CCC fee code is $1605-$ $7422 / 20 / \$ 21.00$.

Printed in the United States of America by Curran Associates, Inc., under license from SPIE.

Publication of record for individual papers is online in the SPIE Digital Library.

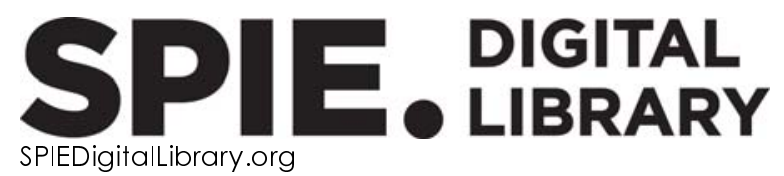

Paper Numbering: Proceedings of SPIE follow an e-First publication model. A unique citation identifier (CID) number is assigned to each article at the time of publication. Utilization of CIDs allows articles to be fully citable as soon as they are published online, and connects the same identifier to all online and print versions of the publication. SPIE uses a seven-digit CID article numbering system structured as follows:

- The first five digits correspond to the SPIE volume number.

- The last two digits indicate publication order within the volume using a Base 36 numbering system employing both numerals and letters. These two-number sets start with 00, 01, 02, 03, 04, 05, 06, 07, 08, 09, OA, OB ... 0Z, followed by 10-1Z, 20-2Z, etc. The CID Number appears on each page of the manuscript. 


\section{Contents}

$\begin{array}{ll}\text { iii } & \text { Authors } \\ \text { iv } & \text { Conference Committee }\end{array}$

MULTIFUNCTIONAL NANOPARTICLES

1125402 Biosensing the presence of nanoparticles using endogenous fluorescence in live algae [11254-1]

1125405 Interaction-free quantum imaging [1 1254-4]

1125407 Sharper and dipper laser beam shaping for super-resolved imaging in silicon [1 1254-6]

1125408 High signal-to-noise, non-bleaching imaging with plasmonic nanoparticles [1 1254-7]

\section{NANOSCALE IMAGING I}

11254 OG NIR-II fluorescence in vivo functional bioimaging (Invited Paper) [11254-15]

$11254 \mathrm{OH}$ Internalization by PMMA nanoparticle-mediated endocytosis of a survivin molecular beacon as theranostic agent in human cancer cells [11254-16]

11254 Ol Remote optical sensing of neuronal tissue vibrations during regeneration [1 1254-17]

NANOSCALE IMAGING II

11254 OK Protein-modified CuS nanotriangles for dual-modal photoacoustic and magnetic resonance imaging [11254-19]

11254 ON Differential uptake of gold-nanorods promotes identification of M1/M2 subtype of macrophage by flow cytometry [1 1254-22]

\section{NANOSTRUCTURES FOR BIOMEDICAL SENSORS I}

11254 OS Enhanced non-contact and continuous sensing of periodic bio-signs: extending sensor's temporal bandwidth (Invited Paper) [1 1254-27] 
$112540 z \quad$ Array-based differential sensing of cancer cells using DNA-templated silver nanoclusters [11254-34]

1125410 Investigation of the effect of pH on lyotropic liquid crystal using Raman spectroscopy [11254-35]

1125411 STED imaging of cytoplasmic RNA in live cells [11254-37]

1125412 Temporal measurement of the entire electric field of ultrafast input signals [1 1254-38]

1125413 Time-lenses placed in an array with overlapping between adjacent time-lenses [11254-39]

$1125414 \quad$ Near-infrared scattering measurements of the iso-path-length point for endoscopic applications [11254-40]

1125416 Extraction of the absorption coefficient of cylindrical tissue from a single wavelength based on the full scattering profile [1 1254-42]

1125418 Spectroscopy measurements of opaque material by nanophotonics iterative multi-plane technique [1 1254-44]

11254 IC Low-cost glucose biosensor fabricated by a photosensitive resin that features nanoparticles [11254-48]

$112541 \mathrm{~F} \quad$ Core/Shell Iron Oxide@Gold nanoparticles for dual-modal CT/MRI imaging [1 1254-51]

$112541 \mathrm{G} \quad$ Multimodal high-resolution imaging of photoreceptor precursor cells using gold nanoparticles [11254-52]

$11254 \mathrm{1H} \quad$ Tracking bacteria clearance using gold nanoparticles for wound therapy applications [11254-53]

$112541 \mathrm{~J} \quad$ Optical flow of vesicles: computer vision approach for endocytosis of nanoparticles in a living cell [11254-36] 


\section{Authors}

Numbers in the index correspond to the last two digits of the seven-digit citation identifier (CID) article numbering system used in Proceedings of SPIE. The first five digits reflect the volume number. Base 36 numbering is employed for the last two digits and indicates the order of articles within the volume. Numbers start with 00, 01, 02, 03, 04, 05, 06, 07, 08, 09, 0A, 0B...0Z, followed by 10-1Z, 20-2Z, etc.

Abdolazimi, Vahideh, 10

Adinolfi, B., $\mathrm{OH}$

Amit, Gal, 05

Baldini, $\mathrm{F} ., \mathrm{OH}$

Ballestri, M., $\mathrm{OH}$

Ben-Eliezer, Noam, $1 \mathrm{~F}$

Betzer, Oshra, 1F, 1G, 1H

Blumenfeld-Katzir, Tamar, $1 \mathrm{~F}$

Boyd, Robert W., 05

Castillo, A. A., 1C

Chakraborty, Ruchira, ON

Chemla, Yoav, $1 \mathrm{G}$

Chen, Yuan-I, $0 Z$

Chorvat, D., 02

Cohen, Eliahu, 05

Cohen, Sharon, 01

Das, Pintu, 11

Dreifuss, Tamar, $1 \mathrm{~F}$

Duadi, Hamootal, 12, 13, 14, 16, 18

Elitzur, Avshalom C., 05

Farah, Nairous, 01

Feder, Idit, 16

Fixler, Dror, 0N, 14, 16, 18, 1G, 1H

Fontecchio, Adam K., 10

Fridman, Moti, 12, 13

Friedman, Ori, 12, 13

Gao, Duyang, OK

Gao, Lu, 05

Giannetti, A., $\mathrm{OH}$

Grenapin, Florence, 05

Gu, Zhenyu, 11

Guzmán, J. V., 1C

Guzman, V., 1C

Halevi, Ariel, ol

Harden, James L., 05

He, Ying, 11

Henneman, Joshua, 10

Higuchi, Hideo, $1 \mathrm{~J}$

Hong, Soonwoo, $\mathrm{OZ}$

Ishikawa, Masatoshi, $1 \mathrm{~J}$

Karimi, Ebrahim, 05

Kim, Hyuno, $1 \mathrm{~J}$

Klein, Avi, 12, 13

Kuo, Yu-An, $0 Z$

Larocque, Hugo, 05

Lee, Seohyun, $1 \mathrm{~J}$

Lee, Somin Eunice, 08

Leshem-Lev, Dorit, ON

Liu, Yen-Liang, $0 Z$
Liu, Yunbo, 08

Liu, Zhuang, IF, $1 \mathrm{G}$

Mandel, Yossi, OI, $1 \mathrm{G}$

Marcek Chorvatova, A., 02

Markus, Amos, $1 \mathrm{G}$

Mateasik, A., 02

Meir, Sara, 12, 13

Motiei, Menachem, 1F, 1G, 1H

Nguyen, Trung, $\mathrm{OZ}$

Omer, Noam, $1 \mathrm{~F}$

Ozana, Nisan, Ol

Pellegrino, M., $\mathrm{OH}$

Piao, Daqing, 14

Polokhin, A. A., 1C

Popovtzer, Rachela, 1F, 1G, 1H

Qian, Jun, OG

Qu, Junle, 11

Sadan, Tamar, 1F, 1G, 1H

Saldana, M. I., 1C

Scanlin, Sarah, 10

Shabairou, Nadav, 07

Shahal, Shir, 12, 13

Shankar, Prathyush, $0 Z$

Shapira, Channa, 18

Shefi, Orit, 이

Shoval, Asaf, 01

Sibony, Inbar, 12, 13

Sinvani, Moshe, 07

Sit, Alicia, 05

Sotgiu, G., $\mathrm{OH}$

Teplicky, T., 02

Tiferet, Maor, 07

Tombelli, S., $\mathrm{OH}$

Topaz, Guy, 1H

Topaz, Moris, $1 \mathrm{H}$

Trono, $\mathrm{C} ., \mathrm{OH}$

Valica, M., 02

Varchi, G., $\mathrm{OH}$

Yang, Zhigang, 11

Yariv, Inbar, 18

Yeh, Hsin-Chih, $\mathrm{OZ}$

Yuan, Zhen, OK

Zalevsky, Zeev, 07, 0l, 0S

Zhang, Dan, 11

Zhang, Jianguo, 11

Zhang, Yingwen, 05

Zilony, Neta, $1 \mathrm{H}$ 
Proc. of SPIE Vol. 11254 1125401-6

\section{Downloaded From: https://www.spiedigitallibrary.org/conference-proceedings-of-spie on 25 Apr 2023
Terms of Use: https://www.spiedigitallibrary.org/terms-of-use}




\title{
Conference Committee
}

\author{
Symposium Chairs
}

Jennifer K. Barton, The University of Arizona (United States)

Wolfgang Drexler, Medizinische Universität Wien (Austria)

Program Track Chairs

Paras N. Prasad, University at Buffalo (United States)

Ewa M. Goldys, The University of New South Wales (Australia)

Conference Chairs

Dror Fixler, Bar-Ilan University (Israel)

Ewa M. Goldys, The University of New South Wales (Australia)

Conference CoChair

Sebastian Wachsmann-Hogiu, University of California, Davis (United States)

Conference Program Committee

Vasily N. Astratov, The University of North Carolina at Charlotte (United States)

Lorena Betancor, Universidad ORT Uruguay (Uruguay)

Henry Hess, Columbia University (United States)

Malgorzata Jędrzejewska-Szczerska, Gdansk University of Technology (Poland)

Sung Jin Kim, University of Miami (United States)

James F. Leary, Purdue University (United States)

Brian D. MacCraith, Dublin City University (Ireland)

Alzbeta Marcek Chorvatova, International Laser Center (Slovakia)

Paras N. Prasad, University at Buffalo (United States)

Sharon M. Weiss, Vanderbilt University (United States)

Session Chairs

1 Multifunctional Nanoparticles

Ewa M. Goldys, The University of New South Wales (Australia)

2 Nanoscale Imaging I

Dror Fixler, Bar-Ilan University (Israel) 
3 Nanoscale Imaging II

Sebastian Wachsmann-Hogiu, McGill University (Canada)

4 Nanostructures for Biomedical Sensors I

Dror Fixler, Bar-Ilan University (Israel)

5 Nanostructures for Biomedical Sensors II

Alzbeta Marček Chorvátová, International Laser Center (Slovakia) 